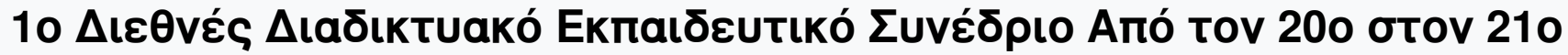

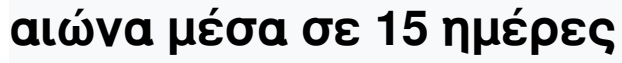

Ap. $1(2021)$

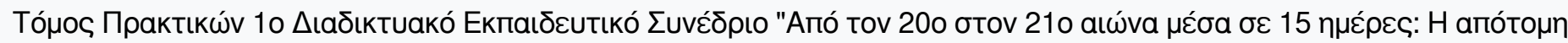

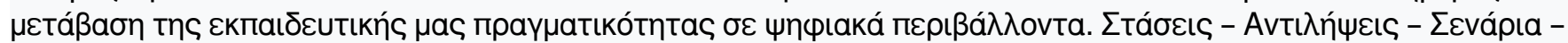

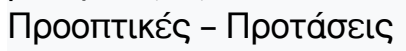

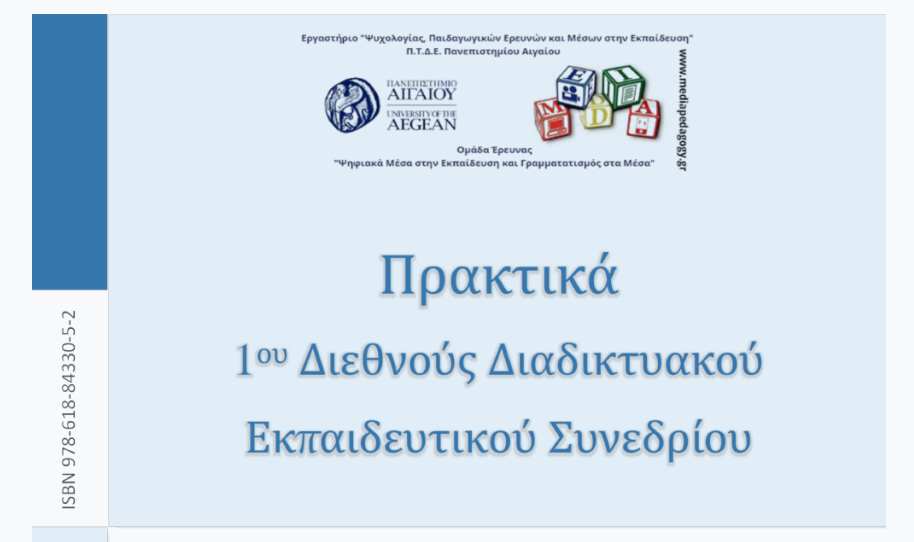

COVID-19 and the urge for digital environments transition in education: reflecting on the Portuguese experience

\section{Teresa Cardoso, Glória Bastos}

doi: $\underline{10.12681 / o n l i n e-e d u .3218}$

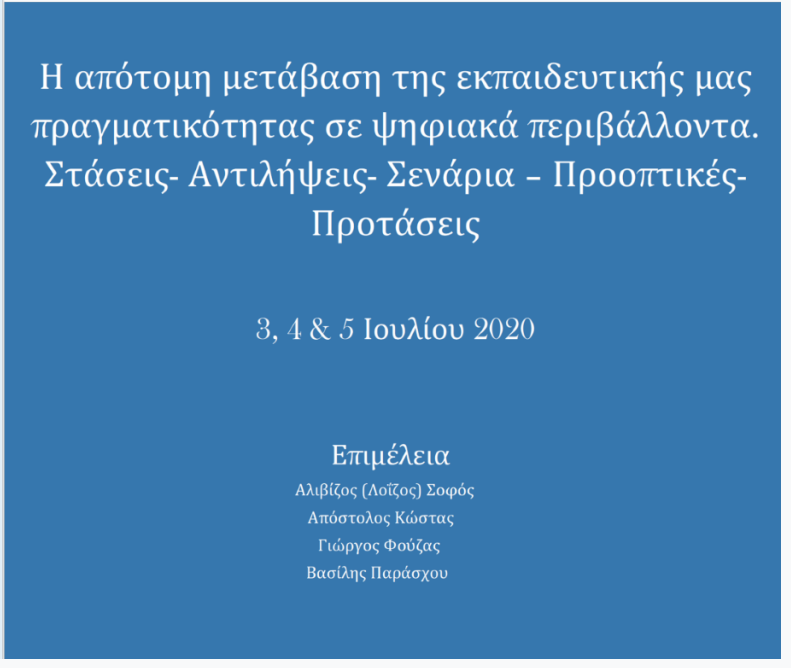

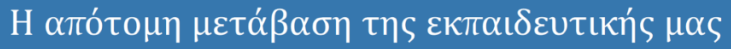

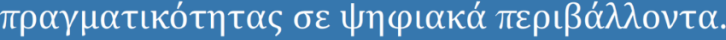

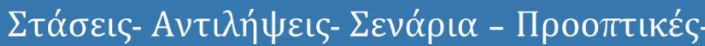

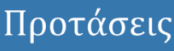

3, 4 \& 5 Iou入íou 2020 


\title{
COVID-19 and the urge for digital environments transition in education: reflecting on the Portuguese experience
}

\author{
Teresa Cardoso ${ }^{1}$, Glória Bastos² \\ teresa.cardoso@uab.pt, gloria.bastos@uab.pt \\ 1 Professor, Universidade Aberta, Portugal, LE@D \\ 2 Professor, Universidade Aberta, Portugal, CEMRI, LE@D
}

\begin{abstract}
With the outbreak of COVID-19, governments worldwide, including in Europe, have taken different actions with regard to the impact in education due to the containment procedures. In Portugal, to help learners and educators to continue with their education and training activities during this period, several measures were put in action, mainly connected with the transition to distance education, at all levels of education. Teachers were pushed to move to online communication with pupils, and to deliver contents and activities using different online tools. But the major problem is that although Portugal has a good internet network, yet some families lack computers/digital devices. On the other hand, many teachers are not still at ease working in digital contexts, lacking necessary skills. To help teachers, Universidade Aberta (Open University, Portugal) has collaborated with the Ministry of Education in a special online training for teachers to develop competences in the creation, design and organization of digital networked environments. In this text, we focus and reflect on these efforts and initiatives, thus presenting some of the Portuguese experiences carried out to address the educational transformations caused by COVID-19.
\end{abstract}

Keywords: COVID-19, Digital Learning Scenarios, Teaching Transformations, Portugal

\section{Introduction}

The context of the COVID-19 pandemic we are living has hastened the digital revolution in different domains of society. Hence, many initiatives, both nationally and internationally, have emerged to provide citizens with the possible best responses to the different challenges we had to face, to those we are still currently facing, and those yet to come.

Therefore, we start by briefly presenting some examples that we highlight to show that digital competences are essential, and desirably available to everyone, not only in this particular moment that we live in, but throughout our life. These cases help us grasp how educational environments have been transformed in the outbreak of COVID-19. Afterwards, we describe examples from the Portuguese experience, and further characterize the response of the Universidade Aberta (UAb), the Portuguese Open University, so as to meet the emerging challenges caused by the new virus. We conclude by evidencing the importance of global resources for the development of local actions within our educational communities.

\section{Transforming educational environments in the outbreak of COVID-19}

Even before the outbreak of COVID-19, agendas worldwide had been emphasizing the need for the $21^{\text {st }}$ citizen to develop a wide array of competences and literacies. Actually, nowadays policies and strategies to improve the digital skills are at stake as governments and other organizations establish a direct relationship between the development of such competences and the qualification of people and their employability (Pinto et al., 2019). Therefore, educational institutions have to formally address these issues too, for example, by integrating them in different programmes, courses and subjects, from basic to higher education.

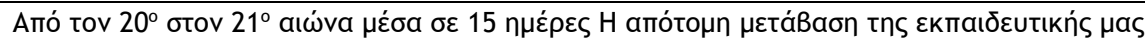

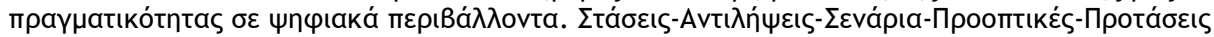


In fact, at least in the Portuguese context, the need to align the curriculum with national initiatives and international actions specifically focused on ICT literacy skills has been felt. This is the case in many documents, including some from the Portuguese Ministry of Education, such as "The Profile of Students Leaving Compulsory Education" (Martins, 2017), in which a set of 10 competencies are defined, as follows:

The areas of competence are complementary, and their enumeration does not imply any internal hierarchy between them. None of them, on the other hand, corresponds to a specific curricular area, and in each curricular area there are multiple competencies involved, both theoretical and practical. They assume the development of multiple literacies, such as reading and writing, numeracy and the use of information and communication technologies, which are foundations to learn and continue to learn throughout life. (p.19)

The above-mentioned foundations are also highlighted in the National Digital Competences Initiative e.2030, Portugal INCoDe.2030, “an integrated public policy to enhance and foster digital competences [...] starting with the promotion of digital inclusion and literacy, educating the young generations from an early age" (INCoDe.2030, 2017, p. 3). Indeed, in its $2^{\text {nd }}$ main action line - education -, the two key premises are again underlined: "Educating the younger population by stimulating and reinforcing digital literacy and digital skills at all levels of schooling and as part of lifelong learning" (p.14).

Another important action, now at a European scale, is the "Opening up Education initiative", aimed at setting the ground to support innovative teaching and learning environments, and aiding teachers to strengthen their digital competences and creative teaching practices (European Commission, 2013). In this context, the use and creation of Open Educational Resources (OER) should be suggested for all, namely teachers and pupils/students, through the use (and creation) of new technologies, namely open source software. More recently, and specifically focused on the need for development of digital competences of educators at all levels of education, the European Framework for the Digital Competence of Educators (DigCompEdu) is another important tool in the process of capacity building for the digital transformation of teaching and learning (Redecker, 2017).

Internationally, that is, at a global scale, we can refer to the United Nations' 2030 Agenda for Sustainable Development (www.un.org/sustainabledevelopment), through its Sustainable Development Goals (SDG), namely SDG 4, on "Quality Education", aimed to ensure access to inclusive, quality, and equitable education, and promote lifelong learning opportunities for all. As Cardoso et al. (2020) acknowledge:

By promoting and creating conditions to implement this SDG 4, we will surely be promoting other SDGs, of which we highlight the following: $5^{\text {th }}$ "Gender Equality"; 8 $^{\text {th }}$ "Decent work and economic growth"; $10^{\text {th }}$ "Reduced inequalities"; $17^{\text {th }}$ "Partnerships for the goals". The integration of these SDGs reflects commitments to ethics, global citizenship, and natural and cultural diversity, $[. .$.$] which we assume in a sustainable development$ logic, both for people and for institutions.

All these actions, among others, have certainly been key to the transitions forced by the COVID-19 confinement. In Portugal, as elsewhere in the world, the mandatory shutting down of the vast majority of the social institutions imposed unforeseen transformations. For instance, almost overnight schools and universities were required to develop distance education plans to carry on with their teaching and learning activities. As a result, teachers, pupils and students, and their families, had to adapt to this immediately shift from face-toface classes to online classes from their homes. In a very short period of time, different

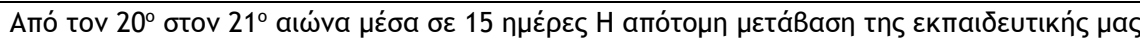

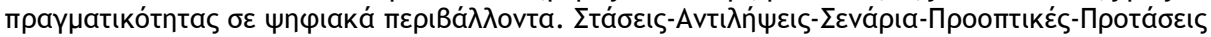


responses to these unexpected and unimaginable challenges were put in place. In the following section, we will address some of them from the Portuguese panorama.

\section{Examples from the Portuguese experience}

In Portugal, and before we look at some specific examples in the provision of alternative learning scenarios to the regular educational environments, it is important to notice the roadmap implementation, with 8 principles, proposed by the Portuguese Directorate-General for Education to guide schools in the development of their Distance Learning Plan (https://www.dge.mec.pt/sites/default/files/roteiro_ead_vfinal.pdf):

1. Mobilizing for change

2. Communicating on a network

3. Deciding on the Distance Teaching model

4. Collaborating and articulating

5. Teaching Methodologies

6. Selecting the technological means of distance teaching

7. Caring for the school community

8. Tracking and monitoring

In addition to these guidelines, the attention was drawn to UNESCO's "10 Recommendations to plan distance learning solutions" (https://en.unesco.org/news/covid19-10-recommendations-plan-distance-learning-solutions), the OECD's "Education responses to covid-19: Embracing digital learning and online collaboration" (https://oecd.dam-broadcast.com/pm_7379_120_120544-8ksud7oaj2.pdf), and, at a national level, to the (Portuguese) National Association of Computer Teachers ANPRI 's "Strategic Digital Mission of the School" (https://drive.google.com/file/d/1XkJDFlTF-KWM4ROBVjHvzwFf1vNOvnn/view).

Moreover, the (Portuguese) Ministry of Education (ME) launched in March 16 th 2020, the day every basic and secondary school was closed, a portal for teachers, called "Apoio às Escolas" - Support for Schools - (https://apoioescolas.dge.mec.pt/), providing a wide range of materials and recommendations, bearing in mind that "Near or far, Education is a right!" (https://apoioescolas.dge.mec.pt/node/391). In this portal, many teachers have also shared their own practices (e.g., videos, lesson plans, etc.) to support the work of their colleagues.

Having a set of concerns related to the security in the use of digital platforms, we want to draw the attention as well to the compliance with the security rules available on the Support for Schools website, produced in close articulation with the National Cybersecurity Centre and the National Data Protection Commission. In fact, the Portuguese Directorate-General for Education, in association with the National Cybersecurity Centre, provides a set of specific security measures for the use of the Google Classroom and Meet platforms, so that their use, in the context of distance learning, takes place in a safe way. These security measures can (and should) also be applied in the use of other digital tools and services. In addition to Google Classroom (and Moodle, in use in most schools before the outbreak of COVID-19), Google Meet and Zoom Colibri were the two most commonly adopted web/videoconference tools for synchronous communication by schools, and therefore by teachers and pupils.

Other Ministry of Education services, such as the "Rede de Bibliotecas Escolares" - School Libraries Network -, have also developed further guidance for teacher librarians to continue to support pupils and teachers at a distance; these resources include several documents, later gathered in an interactive portal, in permanent updated, "A biblioteca escolar digital" - the digital school library - (https://www.digital-rbe.pt/), intended to present work suggestions, content curation, tools and tutorials.

Amó tov $20^{\circ}$ otov $21^{\circ}$ aı

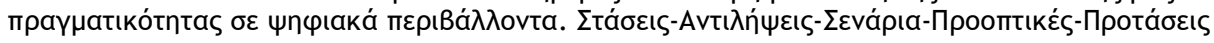


However, and despite the many and rapid actions that were put in place, it quickly became evident that the access of pupils and families to the internet was not (yet) widespread in the whole country, because some regional and suburban contexts were revealing weaknesses in this access. In certain cases, the local authorities (city halls and local councils) ended up by playing a supporting key role, providing many pupils with paper copies of the work that was being done by postal mail. This situation was analyzed as generating inequalities between pupils, with a percentage being able to be monitored online by their teachers, whereas others were monitored by telephone, in a one-to-one synchronous interaction (pupil-teacher), as said, accessing only to the printed materials with the school activities in progress.

Another obstacle is the fact that a number of families in Portugal don't have (yet) at home computers, or other digital device, suitable for distance online classes. To face this setback, a different strategy was built, \#EstudoEmCasa - \#StudyAtHome -, this time in a collaboration between the ME and the RTP (Portuguese Public National TV Broadcasting), with the support of the Calouste Gulbenkian Foundation (a private foundation with an important role in the Portuguese culture scene). The broadcasts started on April 20th , 2020, from Monday to Friday, starting at 09:00 a.m. and ending at 05:50 p.m., according to the timetable on Figure 1 (below); the set of educational contents made available covered all curricular subjects (even Gymnastics), from kindergarten to $9^{\text {th }}$ grade, and were both produced and presented by a large team of teachers. As of June 26th 2020 , the last day of the 2019/2020 school academic year (delayed by 3 weeks according to the initial plan), the numbers - 100,000 viewers, 45 school curricular subjects, and 305 hours of broadcast - show the vast dimension of this entrepreneurial experiment, an enterprise that counted even with a special class from the President of the Portuguese Republic himself.

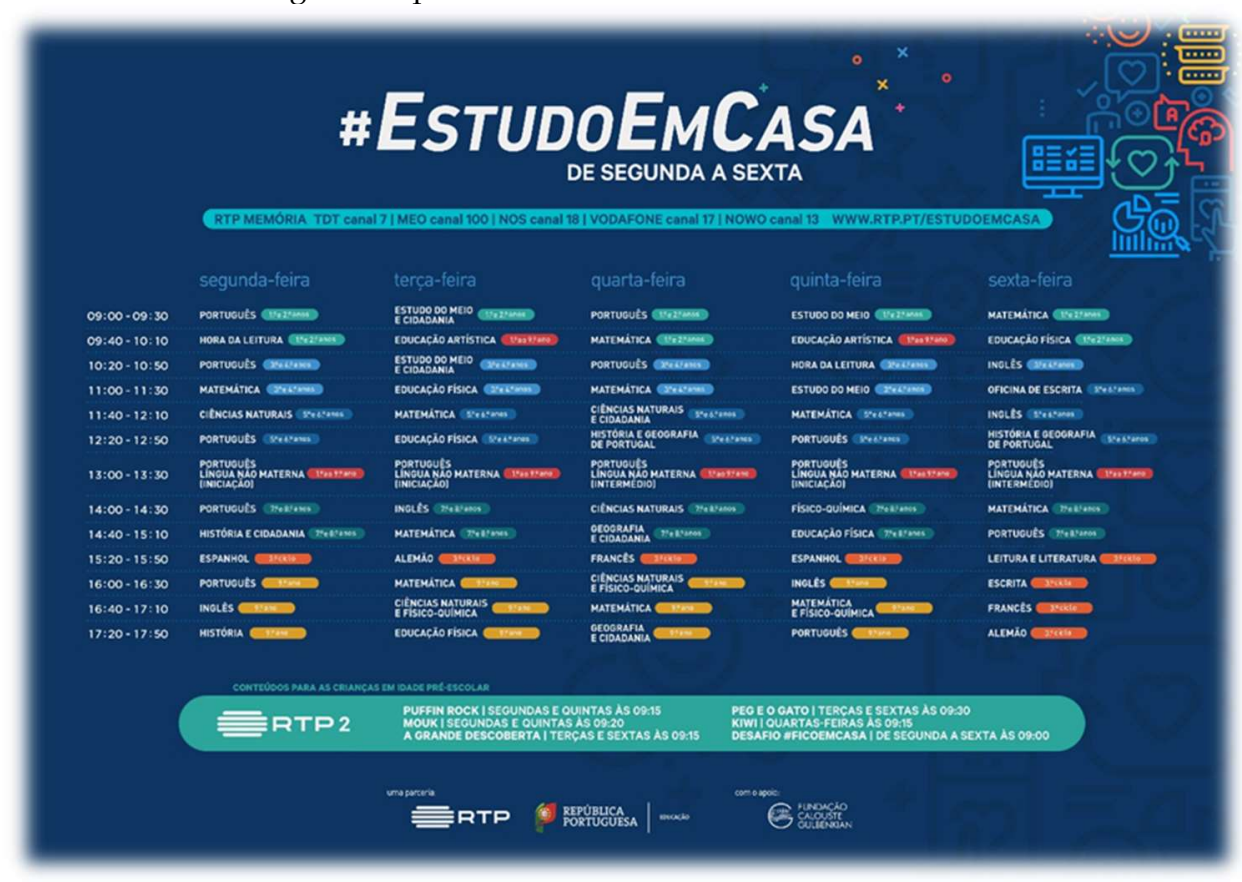

Figure 1. The \#EstudoEmCasa - \#StudyAtHome - weekly timetable grid (https://apoioescolas.dge.mec.pt/node/762)

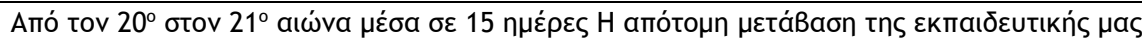

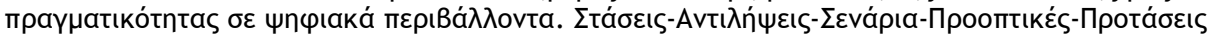


The \#EstudoEmCasa - \#StudyAtHome - was, thus, an additional set of educational resources for both Pre-School Education and Basic Education, broadcasted through the RTP 2 and RTP Memória channels, with unlimited access (free and not dependent on paid services), resulting of the effort of the ME to create and make available multiple resources to support schools. In other words, it was a complement and an extra support means intended primarily for pupils without internet access and/or without digital devices. But it also became to be used by teachers in general, who integrated those broadcasts in the weekly distance education plans of their curricular school subjects. For each of the classes, the topics covered were made available in combination with the essential learning outcomes and school assignments that were intended to be developed; proposals of exercises/challenges that could complement the work of the teachers were also included.

Besides all the institutional initiatives that were carried out, other actions were brought to light, among which those by publishers (such as Porto Editora and LeYa) that facilitated open access to their educational resource platforms linked to the textbooks they edit. Another example is that by a group of Portuguese activists for education and learning, who joined in a project to translate a manual of good practices for the education and training community, edited by UNESCO, which presents the case of China and the way the country maintained its teaching during the pandemic - the Handbook on Facilitating Flexible Learning During Educational Disruption. Many webinars were also facilitated, to address some of the issues related to the design and implementation of distance education environments, which became the rule due to the social confinement imposed on citizens. The media has also been dedicating many news and articles to these ongoing debates, and some lessons are still to be learned, because assessment is needed, i.e. the evaluation is yet to be concluded.

In Higher Education (HE), institutions also took immediate action to ensure the continuity of studies, in some cases even before the Portuguese General Directorate of Higher Education. Under the governmental motto "we do not stop, we are on", had presented an "Evolution of

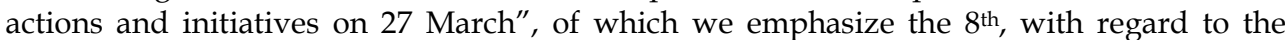
strengthening of the capacity and availability of "a diversified set of services that allow the rapid spread of collaborative and distance learning environments to all higher education institutions, including: COLIBRI, NAU - Always Learning, EDUCAST and VIDEOCAST" (cf. https://www.dges.gov.pt/pt/pagina/covid-19-avisos). In the following section, we describe two specific examples developed within the Universidade Aberta's response to the COVID-19 pandemic.

\section{The response of the Universidade Aberta (Open University Portugal)}

Universidade Aberta (UAb), the online Portuguese public university dedicated to distance education, also had an important role during this pandemic period. On the one hand, by participating in the promotion and dissemination of good practices in distance teaching and learning, through the portal \#SempreLigados - \#AlwaysConnected (https://sites.uab.pt/sempreligados/). This portal offered guides, OER, and other documents related to online teaching and learning. It had also a section dedicated to families, with suggestions about online activities with children.

On the other hand, and as an online university, with 32 years of experience in distance education, $\mathrm{UAb}$ also collaborated with the ME in teacher training, since many teachers still lack the necessary skills and are not yet at ease working in digital contexts. Hence, a specific course named "Formação para a docência digital em rede" - "Training for Digital Network Teaching" - was prepared and delivered to a first group of 2,000 teachers (mostly school principals and principals' assistants) in April/May 2020. This intensive course had tutorial

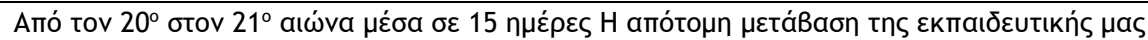

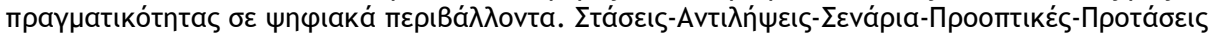


support and mandatory activities for completion; it focused on three topics, during three weeks:

1. Online education and communication, and virtual pedagogical models;

2. Online digital platforms and technologies;

3. E-learning activities and digital assessment.

The main purposes of the course were to meet the new challenges of digital teaching in networks related to different spaces and personalized learning environments; to analyze communication and interaction processes in contexts of digital teaching in networks; to know different pedagogical models for contexts of digital teaching in networks; to design and develop e-activities in digital learning environments; to know and to use digital platforms and technologies, from a communicative and an educational perspective. Ultimately, the aim was to prepare that first group of teachers to disseminate the course, which has happened during May and June among different groups of teachers.

As of today, two interviews can be viewed on the UAb's YouTube channel (https://www.youtube.com/channel/UCyoUs22MPaNdHkKg8cBPOog), with two of the teachers who followed that specific online training. These testimonials are available through the portal of the UAb (https://portal.uab.pt/o-que-dizem-os-docentes/); they enable us to witness brief reflections by Rui Mourinho, a teacher of classical guitar, for whom "To be a teacher is to be constantly learning." And also, by Álvaro Santos, the director of a Portuguese secondary school, who also did the training for Digital Teaching in Network at the UAb; he tells us about the advantages of online education for the school, namely "allowing the restructuring of the content script and the creation of networks of variable geometry".

\section{Conclusions}

In a final reflection, and considering that as teachers in a distance and online university we know very well the requirements and requisites of high-quality online education, it is important to underline that this quick and general move to different forms of distance education cannot be confused with planned online distance education developed by institutions like ours.

This "emergency remote teaching", the adequate term that has been used to describe the situation experienced during Covid-19 (Hodges et al., 2020), arose as an imperative response to the needs imposed by this circumstance of global crisis. The evaluation of all this process still needs to be done, but preliminary observations lead us to the fact that if in HE the process was relatively successful, in the remaining levels of education, many doubts have arisen regarding the learning actually carried out, especially by children. As it has been widely studied (among others: Cercone, 2008; Bastos et al., 2019), online education requires a student profile that is not compatible with the ages of these younger students. This aspect explains, in part, the reason why the ME in Portugal also ended up presenting classes through television as a complementary element of teaching and thus seeking to make learning more effective.

But we have to consider that it has represented an extraordinary effort in basic and secondary education, for both teachers and pupils, as well as parents. The words of João Costa, Assistant Secretary of the Portuguese State and Secretary of Education, who signs the preface of one of the several texts dedicated to these issues (Alves \& Cabral, 2020), express the recognition of this collective effort:

And suddenly, without having time to prepare, the lexical field of the school changed and started to include words such as synchronous class, distance, platform, COVID19, mask, chat, online, [alcohol hand sanitizer] gel... We know that European education systems did not have been affected so negatively since World War II. From one day to the next, schools

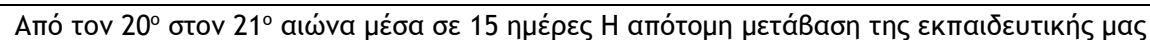

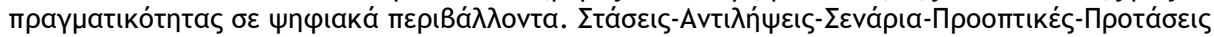


closed and the education system was changed not by will, but by imposition. Portuguese teachers revealed their professionalism and adaptability, schools organized themselves. On the side of the Ministry of Education, we have been producing resources, guidelines, collecting practices, establishing partnerships, to support the work of schools and teachers in this difficult time. (p. 4)

This, or better these difficult times are well-known to both the teachers and the schools. They are familiar to the teacher, because in the construction of their professional identity, as pointed out by Cardoso \& Pestana (in print), teachers must be open "to change, innovation, cooperation, in order to respond to the constant challenges of contemporaneity and creating 'the necessary conditions for the success [...] of permanent education' (Delors, 1996, p. 131)." And they are familiar to the school, because "as an environment conducive to learning and the development of skills, where pupils acquire the multiple literacies they need to mobilize, it has to be reconfigured to respond to the demands of these times of unpredictability and accelerated changes." (Martins, 2017, p. 7)

\section{References}

Alves, J. M., \& Cabral, I. (Eds.) (2020). Ensinar e aprender em tempo de COVID-19: entre o caos e a redenção. Porto: Universidade Católica Portuguesa, Faculdade de Educação e Psicologia.

Bastos, G., Sequeira, R. M., \& Barros, D.M.V. (2019). O papel da educação online na formação de adultos: o caso da Universidade Aberta. Revista Lusófona de Educação, 45, 89-102. Retrieved from https://revistas.ulusofona.pt/index.php/rleducacao/article/view/6993.

Cardoso, T. \& Pestana, F. (in print). Wikipedia as an open educational resource and practice in teacher training. In F. Zoboli (Ed.), Revista Tempos e Espaços em Educação.

Cardoso, T., Pestana, F., \& Pinto, J. (2020). Wikis, Education \& Research: The International Academic Network WEIWER®. EDULEARN20 Proceedings. $12^{\text {th }}$ annual International Conference on Education and New Learning Technologies, EDULEARN20, 8602-8608. Doi: 10.21125/edulearn.2020.2115.

Cercone, K. (2008). Characteristics of adult learners with implications for Online Learning Design. AACE Journal, 16(2), 137-159. Retrieved from https://www.learntechlib.org/primary/p/24286.

European Commission (2013). Opening up Education: Innovative teaching and learning for all through new Technologies and Open Educational Resources. Retrieved from http:/ / bit.ly/2tOq8XE.

Hodges, C., Moore, S., Lockee, B., Trust, T., \& Bond, A. (2020). The Difference between Emergency Remote Teaching and Online Learning. EDUCASE Review. Retrieved from https://er.educause.edu/articles/2020/3/the-difference-between-emergency-remote-teaching-andonline-learning.

Huang, R.H., Liu, D.J., Tlili, A., Yang, J.F., Wang, H.H., et al. (2020). Handbook on Facilitating Flexible Learning during Educational Disruption: The Chinese Experience in Maintaining Undisrupted Learning in COVID-19 Outbreak. Beijing, China: Smart Learning Institute of Beijing Normal University.

INCoDe.2030 (2017). Portugal INCoDe.2030. National Digital Competences Initiative e.2030. Retrieved from http:// bit.ly/37APmrj.

Martins, G. (Coord.) (2017). O perfil dos alunos à saída da escolaridade obrigatória. Lisboa, Portugal: Ministério da Educação.

Pinto, J., Cardoso, T., \& Pestana, F. (2019). Competências Digitais, Qualificação e Empregabilidade: Mapeamento dos documentos em Português com acesso aberto indexados no RCAAP em repositórios portugueses. RE@D - Revista de Educação a Distância e Elearning, 2(1), 26-45. DOI: https://doi.org/10.34627/vol2iss1.

Redecker, C. (2017). European Framework for the Digital Competence of Educators: DigCompEdu. Punie, Y. (Ed). EUR 28775 EN. Publications Office of the European Union, Luxembourg.

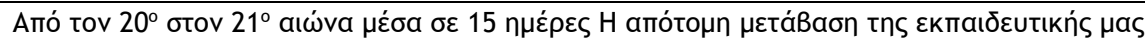

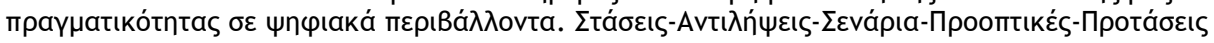

